\title{
Study on the Diversity of Spiders (Order: Araneae) of Lalbagh Botanical Garden and Tavarekere Park, Bangalore South
}

\author{
Selifa Fernandes ${ }^{1}$, Ganesh S. ${ }^{2}$
}

\author{
${ }^{1}$ Department of Zoology, Christ University, Bangaluru, India \\ ${ }^{2}$ Department of Life Sciences, Christ University, Bangaluru, India
}

\begin{abstract}
Spiders belonging to Order Araneae are the largest order in the Class Arachnida and aid in natural pest control. This study focuses on the diversity of spiders in Lalbagh Botanical Garden and Tavarekere Park in Bangalore, Karnataka. The survey was conducted at the respective locations from June to December 2019 which is a period of seven months by using methods like point observation and random sampling using trails. During the study, a total of 21 species belonging to 16 genera and 10 families were documented. Family Salticidea was found to have 6 numbers of species which is the highest as compared to the other families. The statistical analyses and diversity indices were calculated for each study sites. These types of surveys are important for the study of the prevalence of the spider population in given habitats and to create a biodiversity database of spider fauna at the respective study site.
\end{abstract}

Keywords—Diversity, Lalbagh Botanical Garden, Richness, Spider fauna, Tavarekere Park .

\section{INTRODUCTION}

India is known to be a mega diverse country for its high diversity of flora and fauna and contributing to this biodiversity is the Order Araneae which comprises of Spider. Since spiders belong to a group of the most diverse organism, it is necessary to study its diversity as it has been previously neglected or ignored (Palem et al., 2016). Besides its population in forest area, their availability should be checked in the urban areas. Also as the amount of deforestation and settlements increases, there is loss in the natural habitat of spiders (Khan et al., 2019).

In India there are about 1,686 spider species found out of the total species of 44,906 recorded throughout the world. They are considered as biological control agents as they help in maintaining the ecological balance in the nature by feeding on the small insects and in return these spiders are being eaten by birds and other bigger insects (Bhattacharya et al., 2017). The body of spiders is divided into two parts comprising the cephalothorax and abdomen where the cephalothorax has 4 pair of legs and the abdomen does not have any segments (Sebastian \& Peter, 2017). Spiders can't eat solid food, so they have to liquefy the food by using digestive juices and then consume this liquid food (Dharmaraj et al., 2017).
A total number of 51 species belonging to 42 genera of 16 families were documented at Malavagoppa Village in Shimoga district (Kumari \& Shet, 2019) and a 10 families of spiders were recorded in Gulbarga in 2012 (Deshpande\& Paul, 2016). The diversity of Mygalomorphae was found that a total of 111 species under 32 genera and 8 families were seen over 17 states and 2 of the union territories (Dhali et al., 2016), 32 species of spiders belonging to 7 families were observed in different habitats of the University of Pune (Wankhade et al., 2012) and in Aloka, a total of 11 genus and 26 species of family Araenidae were spotted (Shirbhate \& Shirbhate, 2017). A total of 40 species of spiders were recorded which belonged to 36 genera and 11 families in Nilgiris (Dharmaraj et al., 2017), 46 species belonging to 34 genera of 13 families were observed in Tumkuru University (A. L. et al., 2019) and 98 individuals of 11 different species were observed and studied from 10 localities in the Satpuda Mountain (Magare, S. R., 2017). In Gibbon Wildlife Sanctuary, 95 species of spiders belonging to 56 genera and 18 families were recorded (Chetia \& Kalita, 2012), (Oyewole \& Oyelade, 2014) found 1824 individuals of 19 different spider families in Nigeria and 26 species of spiders belonging to 10 families were observed near the River Narmada (Shukla et al., 2015). In the Taleigao Plateue 74 species of spiders belonging to 17 
families were recorded (Pandit \& Pai, 2017), 81 species of spiders under 51 genera from 19 families were documented in Sacred grooves of Odisha (De \& Palita, 2018) and (Halarnkar \& Pai, 2018) revealed the presence of 29 species in one location and 30 species of spiders in other location.

\section{MATERIALS AND METHODS}

\section{Study area:}

The study area is located at Lalbagh Botanical Garden $\left(12.95^{\circ} \mathrm{N} 77.59^{\circ} \mathrm{E}\right)$ and Tavarekere Park $\left(12^{\circ} 55^{\prime} 43^{\prime \prime} \mathrm{N}\right.$ $\left.77^{\circ} 36^{\prime} 10^{\prime \prime} \mathrm{E}\right)$ in Bangalore. The study was carried out from June 2019 to December 2019. The sites are located in the urban area with a good number of vegetation. Study sites are surrounded by human dwellings; and has well maintained garden and open field. Survey was done three or four times a week in the evening hours.

Temperature and humidity was recorded where Lalbagh Botanical Garden showed maximum temperature and Tavarekere Park showed minimum temperature. Humidity ranged from $54 \%$ to $85 \%$ at both the study sites. The flora found at the study location was in wide range.

\section{Sampling methods:}

Random sampling using trails and point observation was done from the selected study sites throughout the year during day (VinodKumari et al., 2017). Collections were done by hand picking, gentle beating on surroundings so as to make the individual pass into the cleared area for better viewing. The collected spiders were photographed using a digital camera (Nikon camera) in live condition identified and then released to their natural habitat (Kumari\&Shet, 2019).

Ground Hand collection is the collection of spider specimen from ground to knee level as it helps to collect the spiders which are found visible on the ground, litter, in broken logs, rocks etc (Shirbhate\&Shirbhate, 2017).

Aerial Hand collection is the collection of spider specimen from knee level to arm length level where the webbuilding and free-living spiders are easily spotted on the foliage and stems of living or dead shrubs, high herbs, tree trunks etc (Shirbhate\&Shirbhate, 2017).

\section{Identification of species:}

The book "Spiders of India" by PA Sebastian and KV Peter was referred for the identification of the recorded spiders. Along with websites like Project Noah and other scientific papers which helped in the identification.

\section{Recording and analyzing data:}

A Record book was used to note down the number of species observed along with the date, time and the environmental factors of the sampling area and also the name of the species were recorded. The data obtained was analyzed using PAST software.

\section{EQUATIONS}

1) Shannon's diversity index, $\mathbf{H}=-\sum \mathbf{P i}(\mathbf{l n P i})$

where $\mathrm{Hl}=$ Shannon Index, $\mathrm{Pi}=$ Proportion of individuals belonging to the ith species

2) Simpson's value, $\mathbf{D}=\sum \mathbf{n i}(\mathbf{n i}-\mathbf{1}) / \mathbf{N}(\mathbf{N}-\mathbf{1})$

whereni $=$ the number of individuals of a species

$\mathrm{N}=$ Total number of all individuals

3) Pielou'sEveness $\mathbf{J l}=\mathbf{H I} / \mathbf{H m a x}$

where $\mathrm{Hl}=$ Shannon value, Hmax = Maximum Shannon value if all the species were equally abundant.

4) Margalef's index $(\mathbf{R})=\mathbf{S}-\mathbf{1} / \mathbf{I n}(\mathbf{N})$

where $\mathrm{R}=$ Margalef's richness index, $\mathrm{S}=$ total of species, $\mathrm{N}=$ total no of individual sample

\section{RESULT AND DISCUSSION}

The total number of spider specimen observed were 129 which comprises of 21 species and 16 genera at Lalbagh Botanical Garden and Tavarekere Park which belonged to 10 families of Order Araneae (Table 1). The highest species diversity was observed at Tavarekere Park with a total number of 17 species observed (Fig 1). The family Salticidae had the highest diversity in the whole study area with 5 genera and 6 species. It followed by family Tetragnathidae which showed 2 genera and 2 species and family Hersilidae has 1 genera and 1 specie and then family Lycosidae has 2 genera and 4 species (Table 2).

The dominant species observed in the study area was Leucaugedecorata, followed by Hersiliasavignyi. Three species of spiders were only observed once at the study location during the entire study period. These species are Ctenuscochinensis, Opadometafastigata and Rheneflavigera. Seven species were common in all the study location and those were Argiope catenulate, Pardosapseudoannulata, Hersiliasavignyi, Pardosabirmanica, Menemerusbivittatus, Oxyopesjavanus, and Oxyopesbirmanicus (Fig 1).

The temperature and humidity played a major role in favouring the diversity of spiders. The highest temperature recorded was $29^{\circ} \mathrm{C}$ in the month of June in Lalbagh Botanical Garden and lowest in the month of September 
and December with $25^{\circ} \mathrm{C}$ in Tavarekere Park( Fig 3).Lalbagh had the highest humidity with $85 \%$ shown in Fig 4.

The diversity indices of spiders in Lalbagh Botanical Garden and Tavarekere Park are shown in table 3. The richness value of spiders was $\mathrm{R}=3.662$ in Tavarekere Park and $\mathrm{R}=2.556$ in Lalbagh Botanical Garden. The diversity calculate by Shannon Weiner's index in Lalbagh was $\mathrm{H}=$ 2.215 and in Tavarekere it showed $\mathrm{H}=2.239$ which comparatively higher. The evenness in Lalbagh was E= 0.8331 and Tavarekere $E=0.552$. The Simpson indices value was higher in Lalbagh with $\mathrm{SIM}=0.8776$ value as compared to Tavarekere with $\mathrm{SIM}=0.8361$ value (Table 3).

Table 1: Total Number Of Specimen Observed

\begin{tabular}{|c|c|c|c|c|c|}
\hline $\begin{array}{l}\text { Sr. } \\
\text { No }\end{array}$ & Family & SPECIES & LALBAGH & TAVAREKERE & TOTAL COUNT \\
\hline 1 & Aranidae & Argiopecatenulata & 4 & 1 & 5 \\
\hline 2 & Corinnidea & Castianeirazetes & 5 & 0 & 5 \\
\hline 3 & Ctenidae & Ctenuscochinensis & 0 & 1 & 1 \\
\hline 4 & Hersiliidae & Hersiliasavignyi & 10 & 13 & 23 \\
\hline \multirow{4}{*}{5} & \multirow{4}{*}{ Lycosidae } & Lycosamackenziei & 0 & 2 & 2 \\
\hline & & Lycosatista & 4 & 0 & 4 \\
\hline & & Pardosapseudoannulata & 2 & 1 & 3 \\
\hline & & Pardosabirmanica & 7 & 1 & 8 \\
\hline 6 & Nephilidae & Herenniamultipuncta & 0 & 5 & 5 \\
\hline \multirow{3}{*}{7} & \multirow{3}{*}{ Oxyopidae } & Oxyopesbirmanicus & 6 & 1 & 7 \\
\hline & & Oxyopesjavanus & 1 & 2 & 3 \\
\hline & & Oxyopeslineatipes & 0 & 2 & 2 \\
\hline 8 & Pholcidae & Smeringopuspallidus & 3 & 0 & 3 \\
\hline \multirow{6}{*}{9} & \multirow{6}{*}{ Salticidae } & Hasariusadansoni & 0 & 4 & 4 \\
\hline & & Menemerusbivittatus & 7 & 2 & 9 \\
\hline & & Myrmarachneorientales & 0 & 5 & 5 \\
\hline & & Myrmarachneplataleoides & 0 & 9 & 9 \\
\hline & & Plexippuspaykulli & 0 & 3 & 3 \\
\hline & & RheneFlavigera & 0 & 1 & 1 \\
\hline \multirow{2}{*}{10} & \multirow{2}{*}{ Tetragnathidae } & Leucauge decorate & 0 & 26 & 26 \\
\hline & & Opadometafastigata & 1 & 0 & 1 \\
\hline & & & & Total & 129 \\
\hline
\end{tabular}


International Journal of Environment, Agriculture and Biotechnology, 5(2)

Available: https://ijeab.com/

Table 2: Number of Family, Genera And Species Of Order Araneae

\begin{tabular}{|l|r|r|}
\hline Family & Genera & Species \\
\hline Araneidae & 1 & 1 \\
\hline Corinnidea & 1 & 1 \\
\hline Ctenidae & 1 & 1 \\
\hline Hersiliidae & 2 & 1 \\
\hline Lycosidae & 1 & 4 \\
\hline Nephilidae & 1 & 1 \\
\hline Oxyopidae & 1 & 3 \\
\hline Pholcidae & 5 & 1 \\
\hline Salticidae & 2 & 6 \\
\hline Tetragnathidae & 1 & 2 \\
\hline
\end{tabular}

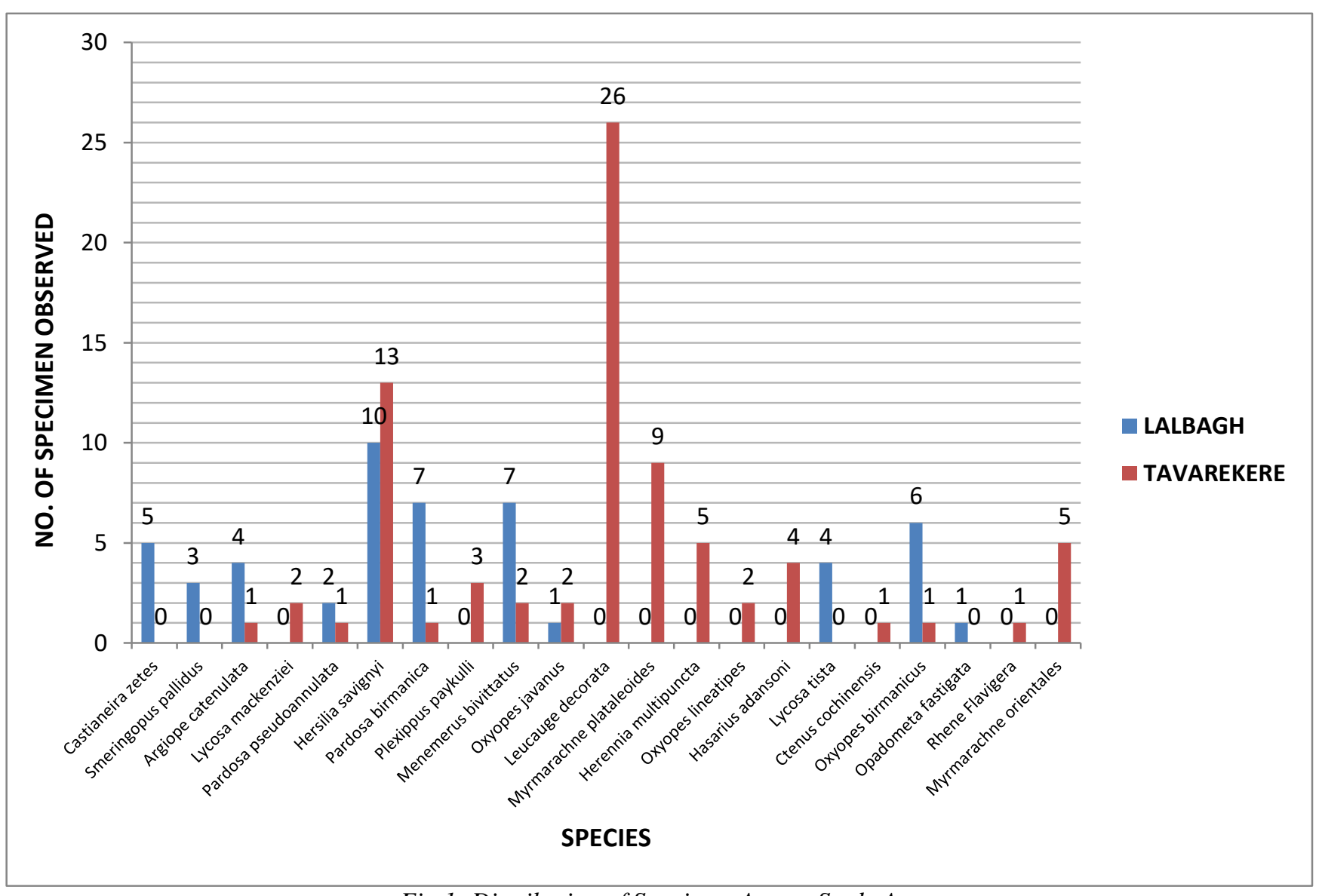

Fig 1: Distribution of Specimen Across Study Area 
International Journal of Environment, Agriculture and Biotechnology, 5(2)

Available: https://ijeab.com/

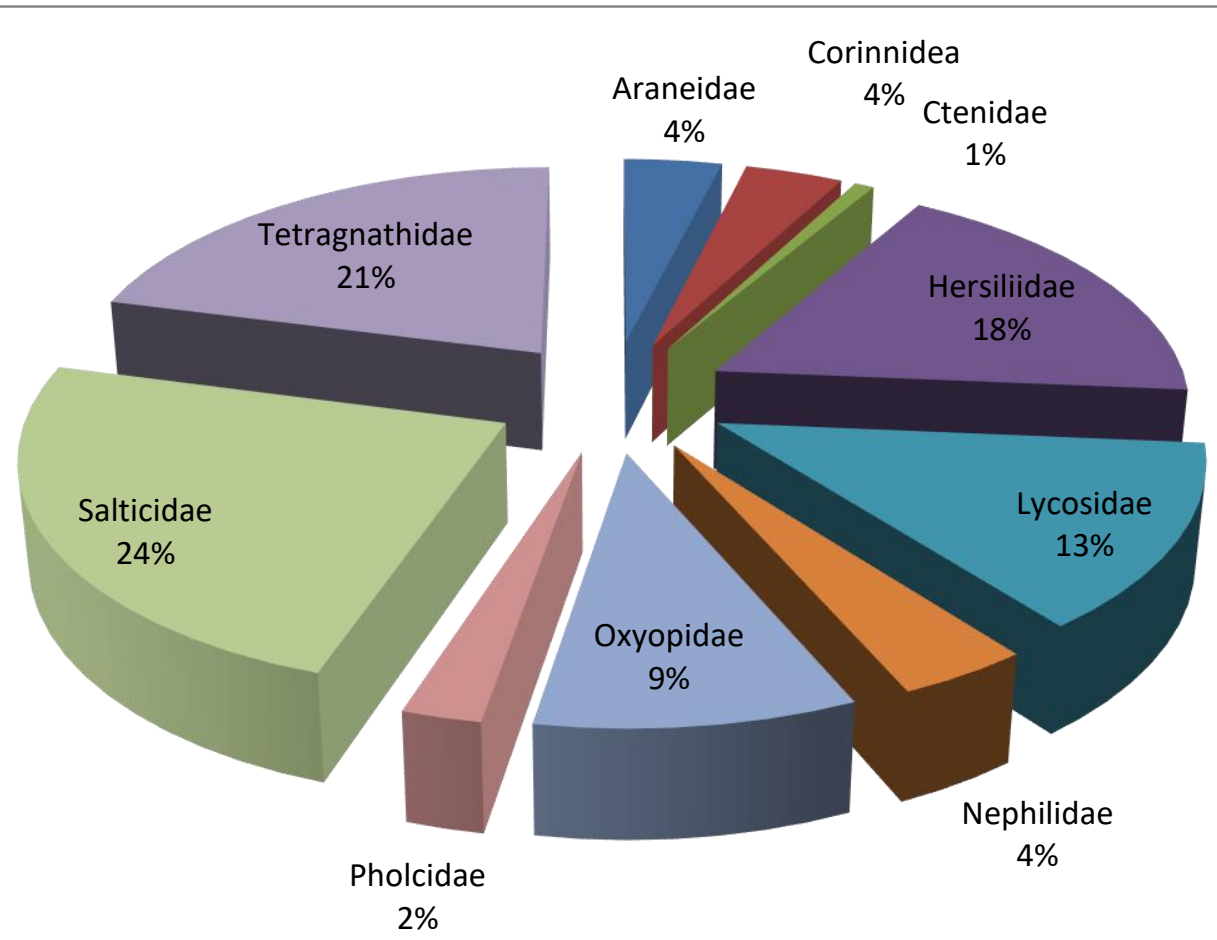

Fig2: Distribution of Araneae Families in the Study Area

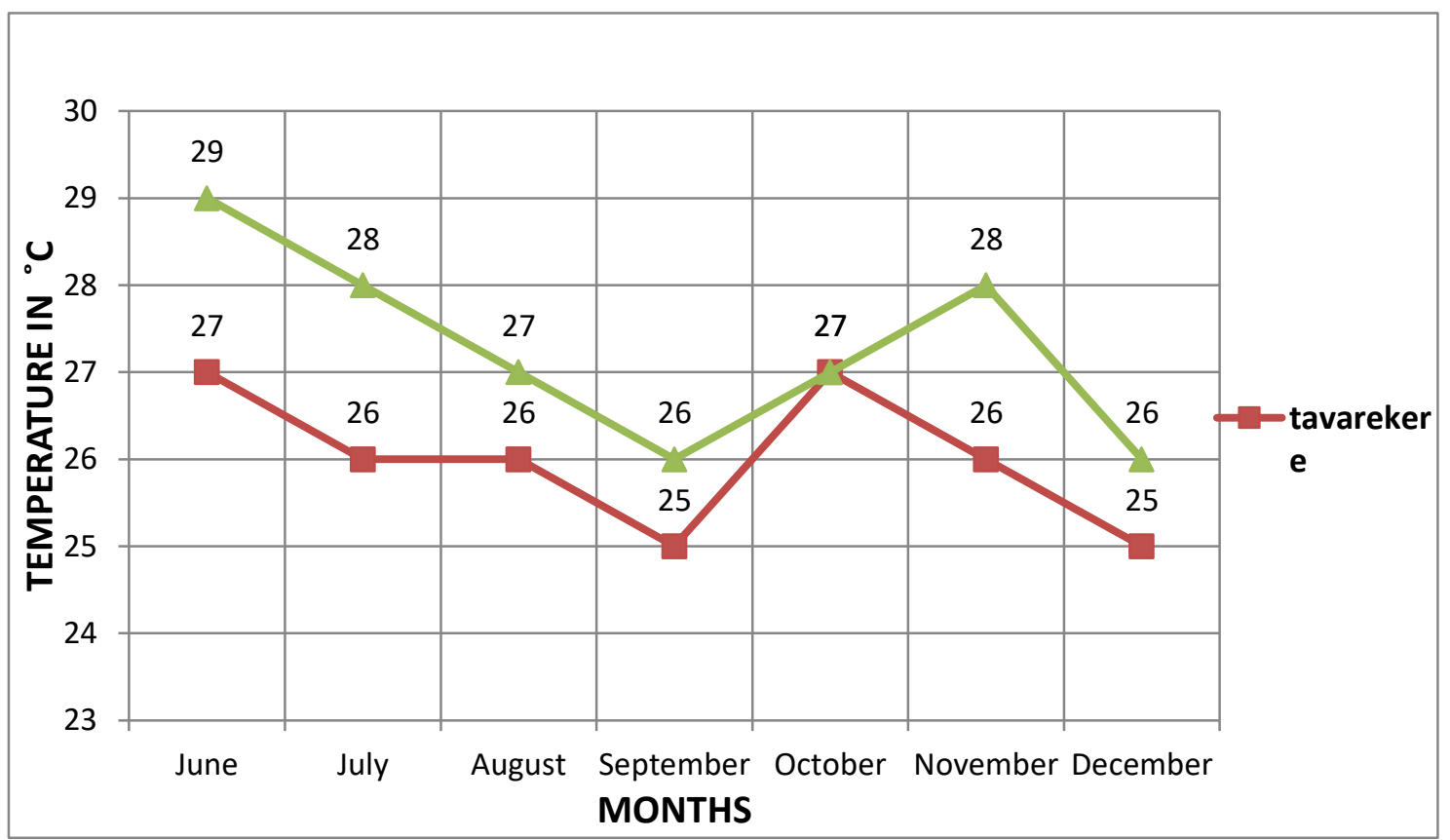

Fig 3: Distribution of Temperature at the Study Area 


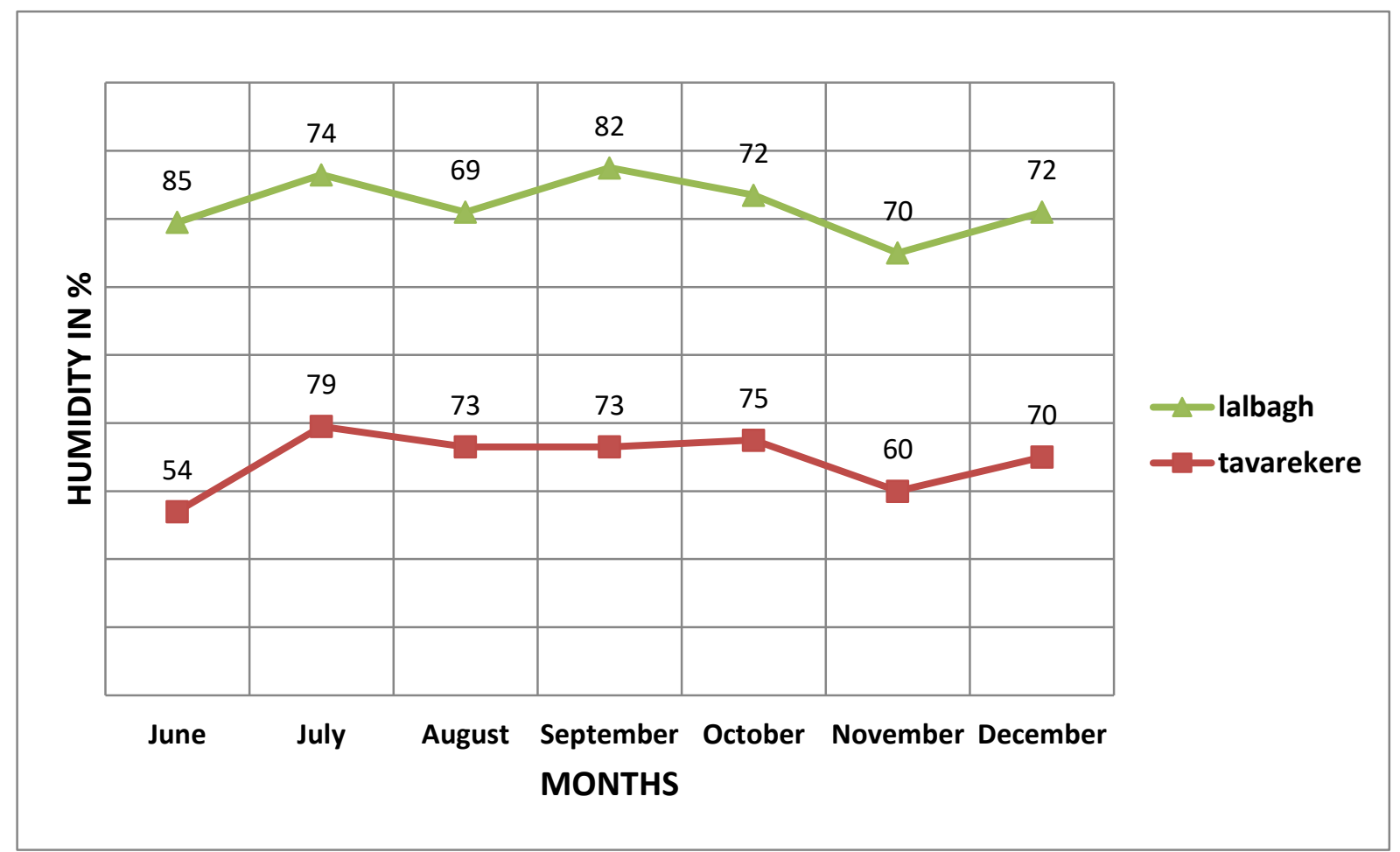

Fig 4: Distribution of Humidity at the Study Area

Table 3: Diversity Indices of Spiders:

\begin{tabular}{|c|c|c|}
\hline & Lalbagh & Tavarekere \\
\hline Taxa_S & 11 & 17 \\
\hline Individuals & 50 & 0.1639 \\
\hline Dominance_D & 0.1224 & 0.8361 \\
\hline Simpson_1-D & 0.8776 & 2.239 \\
\hline Shannon_H & 2.215 & 0.552 \\
\hline Evenness_e^H/S & 0.8331 & 3.662 \\
\hline Margalef & 2.556 & \\
\hline
\end{tabular}

\section{CONCLUSION}

The present study is done at two urban areas to check their diversity and also gives a background for any future studies being done this department. The survey was conducted for a period of seven months from June to December 2019. They help in maintaining the ecological balance of nature as they feed on large population of insect preys. It was seen that Tavarekere Park showed good species diversity and richness as compared to Lalbagh Botanical Garden in Bangalore South as the diversity indices is 2.239 and 2.215 respectively and also with richness being 3.662 and 2.556 respectively. This helps in showing that they are both good predators and preys. There is a need to study the seasonal variation of the spider fauna in these regions and the conservation of this ecosystem which has been a habitat for multiply species of spider fauna.

\section{ACKNOWLEDGEMENTS}

Authors would like to express their gratitude to the Head of Department of Life Sciences Fr. Jobi Xavier and other faculty members for their immense support and also 
thankful to one and all who have directly or indirectly, lent their helping hand in this work.

\section{REFERENCES}

[1] A. L., K., P., L., B.O., R., R., S., \& H.C., G. (2019). A Preliminary Study on Diversity of Spiders from Tumkur University Campus, Tumakuru, India.International Journal of Advanced Scientific Research and Management, 4(2), 84-87. https://doi.org/10.36282/IJASRM/4.2.2019.1153

[2] Bhattacharya, A., Chetri, M., \&Prabal, S. (2017). Spider diversity in different habitats at Jaintia Hills of Meghalaya.Int. J. of Life Sciences, 5(4), 613-619.

[3] Chetia, P., \&Kalita, D. K. (2012). Diversity and distribution of spiders from Gibbon Wildlife Sanctuary, Assam, India.Asian Journal of Conservation Biology, 1(1), 5-15.

[4] De, K., \&Palita, S. K. (2018). A checklist of spiders from six sacred groves in Southern Odisha, India.Serket, 16(1), $30-40$.

[5] Deshpande, A., \& Paul, R. (2016). Preliminary Study on spiders of Gulbarga, Karnataka State.International Journal of Environment, Agriculture and Biotechnology, 1(4), 680 686. https://doi.org/10.22161/ijeab/1.4.9

[6] Dhali, D. C., Sureshan, P. M., \& Chandra, K. (2016). Diversity and Distribution of Indian Primitive Spiders (Araneae: Opisthothelae: Mygalomorphae) in Different State Inculding an Annotated Checklist. World Scientific News, 37, 88-100.

[7] Dharmaraj, J., Gunasekaran, C., Rajkumar, V., \&Chinnaraj, P. (2017). Diversity of spiders (Arachnida: Araneae) in Nilgiris, Tamilnadu. International Journal of Advanced Research in Biological Sciences, 4(5), 143-147.

[8] Halarnkar, M. M., \&Pai, I. (2018). Distribution, Diversity and Ecology of Spider Species At Two Different Habitats. International Journal of Environmental Sciences, 1-6.

[9] Khan, S., Jadhav, A. S., \&Rumani, S. (2019). Biodiversity Of Spider From Different Habitat In Mumbra MaharashtraIndia. Journal of Emerging Technologies and Innovative Research (JETIR), 6(5), 22-31.

[10] Kumari, S., \&Shet, C. (2019). A Study on Diversity of Spiders at Malavagoppa Village, in Shimoga District, Karnataka.International Journal of Environment, Agriculture and Biotechnology, 4(2), 544-555. https://doi.org/10.22161/ijeab/4.2.40

[11] Magare, S. R. (2017). Diversity Of Spiders From Satpuda Mountain, India. Asian Journal of Science and Technology, 8(9), 5539-5542.

[12] Oyewole, O. A., \&Oyelade, O. J. (2014). Diversity and Distribution of Spiders in Southwestern Nigeria.Natural Resources, 05(15), 926-935. https://doi.org/10.4236/nr.2014.515079

[13] Palem, H., Kanike, S., \&Purushottam, V. R. S. (2016). Diversity of Spider Fauna (Arachnida: Araneae) in Different Ecosystems, Eastern Ghats, Southern Andhra Pradesh, India. South Asian Journal of Life Sciences, 4(2),
$51-60$

https://doi.org/10.14737/journal.sajls/2016/4.2.51.60

[14] Pandit, R., \&Pai, I. (2017). Spiders of Taleigao Plateau, Goa, India.Journal of Environmental Science and Public Health, 01(04), 240-252. https://doi.org/10.26502/jesph.96120022

[15] Sebastian, P. A., \& Peter, K. V. (2017). Spiders of India. Universities Press (India) Private Limited.

[16] Shirbhate, M. V., \&Shirbhate, A. M. (2017). Diversity and distribution of Spider fauna (family- Araneidae) in and around Katepurna Sanctuary, Akola, India.Environment Conservation Journal, 18(3), 9.

[17] Shukla, A., Mishra, S., \&Rai, S. (2015). Preliminary Study On Faunal Diversity Of Spider Around River Narmada, Jabalpur Division (Madhya Pradesh). International Journal of Current Research, 7(12), 23487-23489.

[18] Vinod Kumari, Kailash Chand Saini, \& N. P. Singh.(2017). Diversity and distribution of spider fauna in arid and semiarid region of Rajasthan.Journal of Biopesticides, 10(1), $17-24$.

[19] Wankhade, V. W., Manwar, N. A., Rupwate, A. A., \&Raut, N. M. (2012). Diversity and abundance of spider fauna at different habitats of University of Pune, M. S. (India).Global Advanced Research Journal of Environmental Science and Toxicology, 1(8), 203-210. 